\title{
Pelatihan dan Pendampingan Manajemen Perpustakaan Sekolah Berbasis Teknologi Informasi
}

\author{
Setiawan *1, Moch. Syahri ${ }^{2}$, Dwi Novita Ernaningsih ${ }^{3}$, Inawati ${ }^{4}$, Amalia Nurma Dewi $^{5}$ \\ 1,2,3,4,5 Program Studi Ilmu Perpustakaan, Fakultas Sastra, Universitas Negeri Malang \\ *e-mail: setiawan@um.ac.id ${ }^{1}$, moch.syahri.fs@um.ac.id ${ }^{2}$, dwi.novita@um.ac.id², inawati.fs@um.ac.id, \\ AmaliaNurmaDewi@gmail.com ${ }^{5}$
}

\begin{abstract}
Complex issues in school libraries are very diverse, from human resources, budget funds, book procurement, the technology system used is something that deserves attention, because the purpose of the school library is as a learning center, and information, as a learning resource center means that the school must try and clean up to present the latest collections, informative and according to the needs of the school. The school library has a very important role in the success of education. Therefore, school library facilities need attention. One of the facilities that help librarian activities is information technology-based library management. With library management, all library activities can run according to good library standards. Also, students can more easily and freely take advantage of the library collections in it. Information technologybased library management is activities that aim to assist library managers, the school, in creating libraries that comply with the standards set by the National Library. The activities carried out include (a) Providing information about how to manage library services, especially the Tsanawiyah library in Probolinggo Regency. (b) Providing knowledge on the procedures for managing the library at the Information Technology-based Tsanawiyah Library 2. (c) Instilling skills in Tsanawiyah library managers while studying. MTsN 2 Malang is under the auspices of the Ministry of Religion, course it must also have a good library, well managed, and course there is a role for the teaching staff in the library department to make the library the heart of information and the heart of education.
\end{abstract}

Keywords: School library, Information Technology

\begin{abstract}
Abstrak
Persoalan yang komplek di perpustakaan sekolah sangatlah beragam, dari SDM, anggaran dana, pengadaan buku, sistem teknologi yang digunakan merupakan hal yang patut di perhatikan, karna tujuan dari perpustakaan sekolah adalah sebagai pusat belajar, dan informasi, sebagai pusat sumber belajar berarti pihak sekolah harus berupaya dan bebenah untuk menyajikan koleksi-koleksi terbaru, informatif dan sesuai dengan kebutuhan di sekolah tersebut. Perpustakaan sekolah memiliki peran yang sangat penting bagi keberhasilan pendidikan. Karenanya, fasilitas perpustakaan sekolah perlu mendapat perhatian. Salah satu fasilitas yang sangat membantu aktivitas kepustakawanan adalah pengelolaan perpustakaan berbasis teknologi informasi. Dengan adanya pengelolaan perpustakaan, maka semua kegiatan perpustakaan bisa berjalan sesuai dengan standard perpustakaan yang baik. Selain itu, peserta didik dapat lebih mudah dan bebas dalam memanfaatkan koleksi pustaka yang ada di dalamnya. Pengelolaan manajemen perpustakaan berbasis teknologi informasi merupakan kegiatan yang bertujuan untuk membantu pengelola perpustakaan, pihak sekolah, dalam mewujudukan perpustakaan yang sesuai dengan standard yang ditetapkan oleh pepustakaan Nasional Kegiatan-kegiatan yang dilakukan meliputi (a) Memberikan informasi tentang bagaimana mengelola layanan perpustakaan, khususnya perpustakaan Tsanawiyah se-Kabupaten Probolinggo. (b) Memberikan bekal pengetahuan tentang tata cara pengelolaan perpustakaan Perpustakaan Tsanawiyah Negeri 2 berbasis Teknologi Informasi.(c) Menanamkan keterampilan pada para pengelola perpustakaan Tsanawiyah se-belajar. MTsN 2 Malang ada dibawah naungan kementrian Agama, tentunya juga harus memiliki perpustakaan yang baik, dikelola dengan baik juga, dan tentunya ada peran dari para tenaga pengajar di jurusan perpustakaan untuk menjadikan perpustakaan sebagai jantungnya informasi dan jantungnya pendidikan
\end{abstract}

Kata kunci : Perpustakaan sekolah, Teknologi Informasi 


\section{PENDAHULUAN}

Perpustakaan mempunyai peranan penting sebagai jembatan menuju penguasaan ilmu pengetahuan yang dapat menjadi sebuah kekuatan untuk mencerdaskan bangsa. Selain itu, perpustakan juga berfungsi sebagai sumber informasi dan merupakan penunjang penting bagi pelaksanaan suatu riset ilmiah. Perpustakaan memberikan kontribusi penting bagi terbentuknya informasi tentang ilmu pengetahuanSecara garis besar bagian pendahuluan memuat latar belakang, perumusan masalah, tujuan kegiatan, dan kajian literatur. Penulis dituntut mengemukakan secara kuantitatif potret, profil, dan kondisi khalayak sasaran yang dilibatkan dalam kegiatan pengabdian kepada masyarakat. Dapat digambarkan pula kondisi dan potensi wilayah dari segi fisik, sosial, ekonomi, maupun lingkungan yang relevan dengan kegiatan yang dilakukan. Paparkan pula potensi yang dijadikan sebagai bahan kegiatan pengabdian kepada masyarakat. Penulis diminta merumuskan masalah secara konkrit dan jelas pada bagian ini. Jelaskan tujuan yang hendak dicapai pada kegiatan pengabdian. Di perpustakaan sekolah peserta didik dapat mengembangkan minat mereka, mencari bacaan yang memperkaya pengalaman melalui buku yang tersedia. Melalui perpustakaan sekolah, diharapkan peserta didik dapat mengembangkan keterampilan untuk mencari informasi guna keperluan mereka secara mandiri (Marlinda, 2004).

Persoalan dari perpustakaan sekolah, terlebih-lebih perpustakaan MTs memiliki persoalan yang komplek, terlihat jelas dari beberapa pengamatan yang di lakukan oleh tim pengabdian perpustakaan ini, masih banyak perpustakaan sekolah dibawah naungan kementrian Agama yang kondisi rill dilapangan tidak layak sebagai perpustakaan sekolah, sehingga bukan tidak mungkin siswa jarang atau sama sekalipun tidak datang keperpustakaan, persoalan kedua ada ruang perpustakaan dan koleksinya tetapi tidak tertata dengan baik, karena juga tidak memliki petugas yang bisa fokus mengurusi perpustakaan itu, ketiga ada perpustakaan dan koleksi dan juga petugasnya namun petuganya tidak paham bagaimana mengelola perpustakaan dengan baik, terlebih-lebih berdasar standar perpustakaan. Keempat banyak perpustakaan yang sudah memiliki komputer namun tidak dimanfaatkan untuk kebutuhan perpustakaan sekolah, yaitu pelayanan perpustakaan, baik membaca ataupun meminjam buku, selama ini hanya dapat dilakukan kalau pemustaka (siswa) datang ke perpustakaan. Selain itu, informasi mengenai koleksi buku yang tersedia di perpustakaan hanya dapat diakses apabila pemustaka mengunjungi perpustakaan tersebut dan membuka-buka katalog buku. Itu pun, pemustaka tidak dapat langsung mengetahui apakah buku yang dikehendakinya tersedia di rak buku ataukah sedang dipinjam pemustaka lain Ia baru akan tahu bahwa buku tersebut ada atau tidak setelah menghampiri rak buku, atau bertanya kepada petugas sirkulasi perpustakaan. Dalam hal ini, petugas pun tidak dapat dengan segera mengetahui ada/tidaknya buku yang diinginkan siswa sebab ia harus membaca deretan- deretan kertas yang menjadi bukti peminjaman buku oleh pemustaka. Keenam petugas perpustakaan sering mengalami kendala dalam pengolahan data yang masih bersifat konvensional (berbasis kertas). Keterbatasan sebagai manusia membuatnya rentan terhadap kesalahan. Penyimpanan dalam bentuk lembaran-lembaran kertas memiliki resiko hilang atau rusak. Pencatatan data-data perpustakaan yang semakin banyak juga mengakibatkan terjadinya penumpukan kertas yang dapat mempersempit ruangan, dan pada akhirnya akan mengurangi kenyamanan pengunjung perpustakaan. Selain itu, Mengingat ketidakefisienan sistem operasional Perpustakaan MTsN 2 Kota malang, dan mempertimbangkan perkembangan teknologi informasi yang dewasa ini meningkat pesat, kiranya perlu dilakukan pembenahan terhadap sistem operasional perpustakaan di sekolah tersebut. Perlu ada terobosan baru guna meningkatkan kualitas dan kuantitas layanan kepada pengguna perpustakaan sekolah. Terobosan yang dimaksud meliputi perubahan dalam pengolahan data perpustakaan yang masih bersifat konvensional menjadi berbasis komputer 


\section{METODE}

Kegiatan ini berbentuk Pelatihan dan Pendampingan Manajemen Perpustakaan Sekolah Berbasis Teknologi Informasi (SliMS 8.3.1 Akasia) di Perpustakaan Madrasah Tsanawiyah Negeri 2 Malang. Kegiatan ini difokuskan untuk para petugas, guru, siswa dan pustakawan MTs Negeri 2 Malang.

Metode yang digunakan dalam kegiatan pengabdian masyarakat ini, meliputi ceramah, diskusi, dan praktek pengolahan bahan pustaka, serta praktek instalasi teknologi informasi (Slim). Penyampaian informasi untuk materi yang bersifat umum dan teoritis, dalam hal ini adalah materi manajemen perpustakaan dan Gerakan Literasi, pengolahan bahan pustaka, layanan perpustakaan Sekolah yang disertai dengan pemberian tugas-tugas yang sudah dilakukan oleh pihak sekolah dalam mendukung/ Melaksanakan manajemen perpustakaan berbasis teknologi informasi. Kegiatan diawali dengan pre-test untuk mengukur sejauh mana pemahaman peserta terhadap teknologi Informasi dan Pengolahan bahan pustaka. Sedangkan untuk materi teknologi informasi selain ceramah, diskusi juga dilakukan dengan praktek dengan tujuan peserta bisa memahami, dan juga bisa mempraktekkan materi tersebut.

Metode yang akan dilakukan untuk menyelesaikan permasalahan di Perpustakaan MTs Negeri 2 Malang disampaikan sebagai berikut.

Tabel 1. Permasalahan Mitra dan Metode Pelaksanaan Kegiatan

\begin{tabular}{|c|c|c|c|c|}
\hline No & Permasalahan Mitra & Pelaksana & Waktu & Metode \\
\hline 1 & $\begin{array}{l}\text { Pengetahuan umum } \\
\text { terkait Teknologi } \\
\text { Informasi dan } \\
\text { perpustakaan di } \\
\text { MTsN } 2 \text { Kota Malang }\end{array}$ & $\begin{array}{l}\text { Tim } \\
\text { Pengabdian }\end{array}$ & $\begin{array}{l}3 \text { April- } 3 \text { Mei } \\
2020\end{array}$ & $\begin{array}{l}\text { Melakukan Pre-Test } \\
\text { ( Mengukur pemahaman peserta pelatihan) }\end{array}$ \\
\hline 2 & $\begin{array}{l}\text { Kondisi rill } \\
\text { perpustakaan tidak } \\
\text { layak sebagai } \\
\text { Perpustakaan MTs }\end{array}$ & $\begin{array}{l}\text { Tim } \\
\text { Pengabdian }\end{array}$ & $\begin{array}{l}3 \text { Mei- } 21 \\
\text { September } \\
2020\end{array}$ & $\begin{array}{l}\text { Memberikan bimbingan kepada pengelola } \\
\text { perpustakaan terkait pengelolaan } \\
\text { perpustakaan berdasar standar yang di } \\
\text { berlakukan oleh perpustakaan nasional }\end{array}$ \\
\hline 3 & $\begin{array}{l}\text { Negeri } 2 \text { Malang } \\
\text { Ruang perpustakaan } \\
\text { dan koleksinya } \\
\text { tidak tertata dengan } \\
\text { baik }\end{array}$ & $\begin{array}{l}\text { Tim } \\
\text { Pengabdian }\end{array}$ & $\begin{array}{l}3 \text { Mei- } 21 \\
\text { September } \\
2020\end{array}$ & $\begin{array}{l}\text { Memberikan bimbingan dan } \\
\text { Melakukan pendampingan kepada } \\
\text { pengelola perpustakaan terkait pengelolaan } \\
\text { perpustakaan berdasar standar yang di } \\
\text { berlakukan oleh perpustakaan nasional }\end{array}$ \\
\hline 4 & $\begin{array}{l}\text { Petugas } \\
\text { perpustakaan tidak } \\
\text { paham mengelola } \\
\text { perpustakaan } \\
\text { dengan baik }\end{array}$ & $\begin{array}{l}\text { Tim } \\
\text { Pengabdian }\end{array}$ & $\begin{array}{l}3 \text { Mei- } 21 \\
\text { September } \\
2020\end{array}$ & $\begin{array}{l}\text { Memberikan bimbingan kepada } \\
\text { pengelola perpustakaan terkait pengelolaan } \\
\text { perpustakaan berdasar standar yang di } \\
\text { berlakukan oleh perpustakaan nasional }\end{array}$ \\
\hline 5 & Teknologi Informasi & $\begin{array}{l}\text { Tim } \\
\text { Pengabdian }\end{array}$ & $\begin{array}{l}3 \text { Mei- } 21 \\
\text { September } \\
2020\end{array}$ & $\begin{array}{l}\text { Memberikan bimbingan dan } \\
\text { Melakukan pendampingan kepada } \\
\text { pengelola perpustakaan, degan melakukan } \\
\text { install Slim } \text { untuk memudahkah } \\
\text { pengelolaan perpustakaan berbasis }\end{array}$ \\
\hline 6 & $\begin{array}{l}\text { Evaluasi Hasil } \\
\text { Pelatihan }\end{array}$ & $\begin{array}{l}\text { Tim } \\
\text { Pengabdian }\end{array}$ & $\begin{array}{l}3 \text { Mei- } 21 \\
\text { September } \\
2020\end{array}$ & $\begin{array}{l}\text { Melakukan Post test untuk mengukur sejauh } \\
\text { mana pemahaman peserta terhadap } \\
\text { pelatihan yang di peroleh }\end{array}$ \\
\hline
\end{tabular}




\section{HASIL DAN PEMBAHASAN}

A. Hasil

Dalam pengabdian ini, penulis mendapatkan beberapa data yang dapat membantu penulis dalam mengambil sebuah kesimpulan dari pengbdian masyarakat ini . Data yang didapatkan oleh penulis, antara lain secara rinci, rancangan kegiatan Pelatihan dan Pendampingan Perpustakaan Sekolah Berbasis Teknologi Informasi (SliMS 8.3.1 Akasia) di Perpustakaan Madrasah Negeri 2 Malang tersebut disampaikan sebagai berikut:

Pelaksanaan pengabdian yang dilakukan oleh Tim S1 Ilmu perpustakaan Universitas Negeri Malang dilaksanakan pada hari senin 27 Juli 2020 dengan menerapkan protokol kesehatan

- Surat Tugas Pengabdian
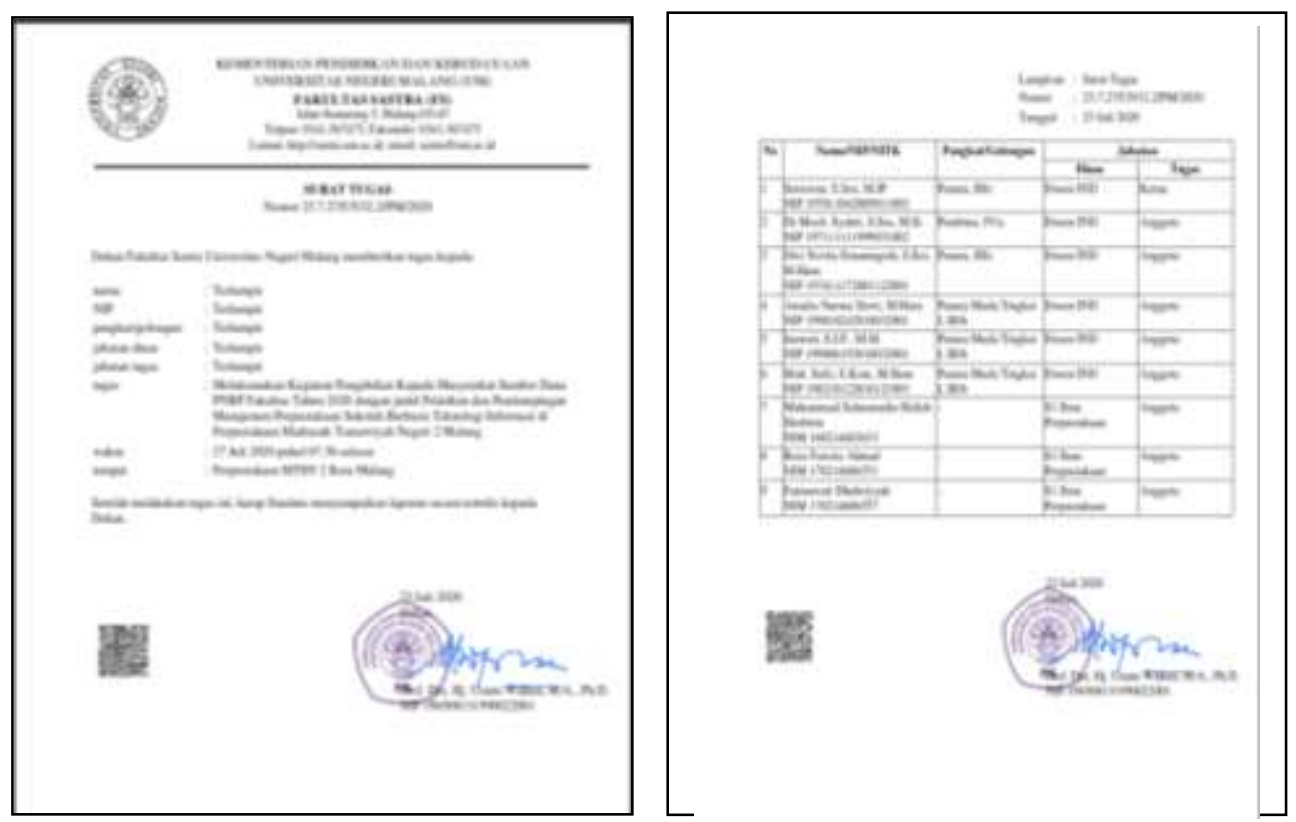

Gambar 1. Surat Tugas pengabdian

- Data Peserta

Data peserta Pelatihan dan Pendampingan Perpustakaan Sekolah Berbasis Teknologi Informasi (SliMS 8.3.1 Akasia) di Perpustakaan Madrasah Negeri 2 Malang.

Tabel 2. Data peserta

\begin{tabular}{clcc}
\hline No & \multicolumn{1}{c}{ Jenis kelamin } & f & $\%$ \\
\hline 1 & Laki-laki & 7 & 53 \\
2 & Perempuan & 6 & 47 \\
& Jumlah & 13 & 100 \\
\hline
\end{tabular}

Data peserta pengabdian ini dari tabel 1 didapat bahwa peserta jenis kelamin laki-laki sebanyak 7 orang dengan persentase 53\% sedangkan peserta dengan jenis kelamin 
perempuan sebanyak 18 orang dengan persentase $47 \%$ peserta ini terdiri dari Tenaga Perpustakaan, guru dengan tugas tambahan menjadi petugas perpustakaan, pimpinan sekolah.

Tabel 3. Status peserta

\begin{tabular}{clcc}
\hline No & \multicolumn{1}{c}{ Jenis kelamin } & f & \% \\
\hline 1 & Tenaga perpustakaan & 2 & 15,38 \\
2 & Guru pustakawan & 1 & 7,69 \\
3 & Guru & 8 & 61,53 \\
4 & Pimpinan & 2 & 15,38 \\
& Jumlah & 30 & 100 \\
\hline
\end{tabular}

Data peserta berdasarkan status peserta berdasarkan tabel 3 didapat peserta berasal dari tenaga perpustakaan sejumlah 2 dengan persentase 15,38\%, Guru Pustakawan yang artinya guru dengan tugas tambahan menjadi kepala perpustakawan sebanyak 1 dengan $7,69 \%$, Guru biasa sebanyak 8 orang dengan persentase 61,53\%, pimpinan yang terdiri kepala sekolah dan kepala tata usaha sebanyak 2 orang dengan presentase $15,38 \%$

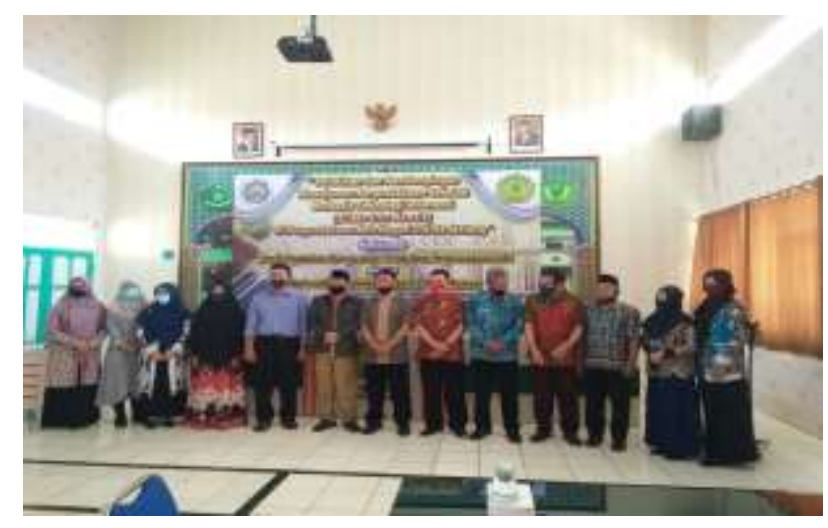

Gambar 2. Foto bersama pimpinan dan pemateri

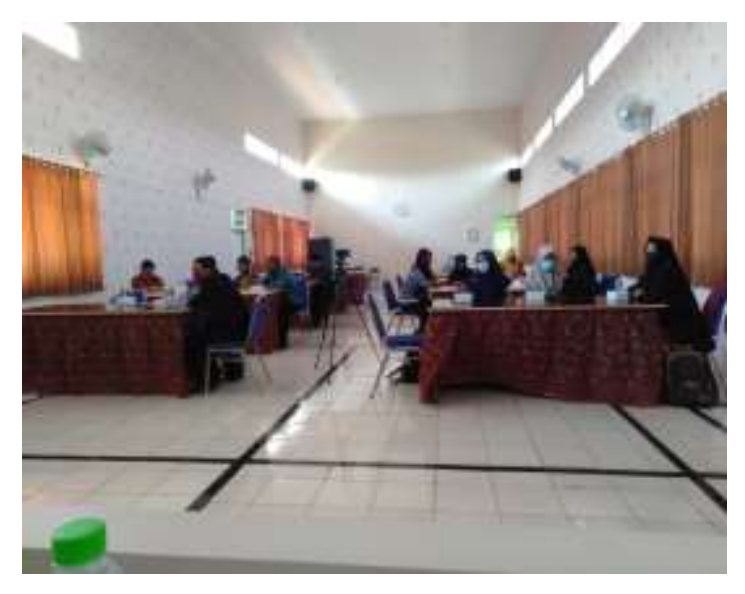

Gambar 3. Peserta 


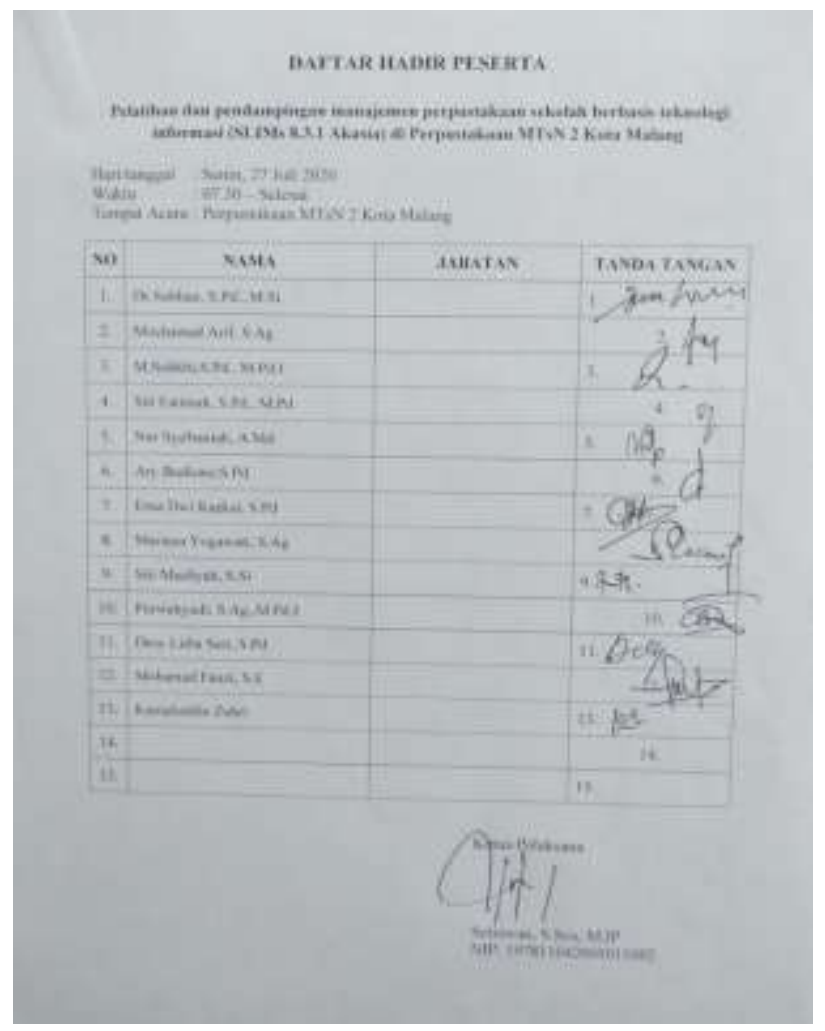

Gambar 4 Daftar Hadir

- Pre-test

Kegiatan Pengabdian diawali dengan pre test yang tujuannya untuk mengetahui pemahaman peserta terhadap Teknologi informasi dan perpustakaan, hasil dari pre test terangkum dalam data berikut .

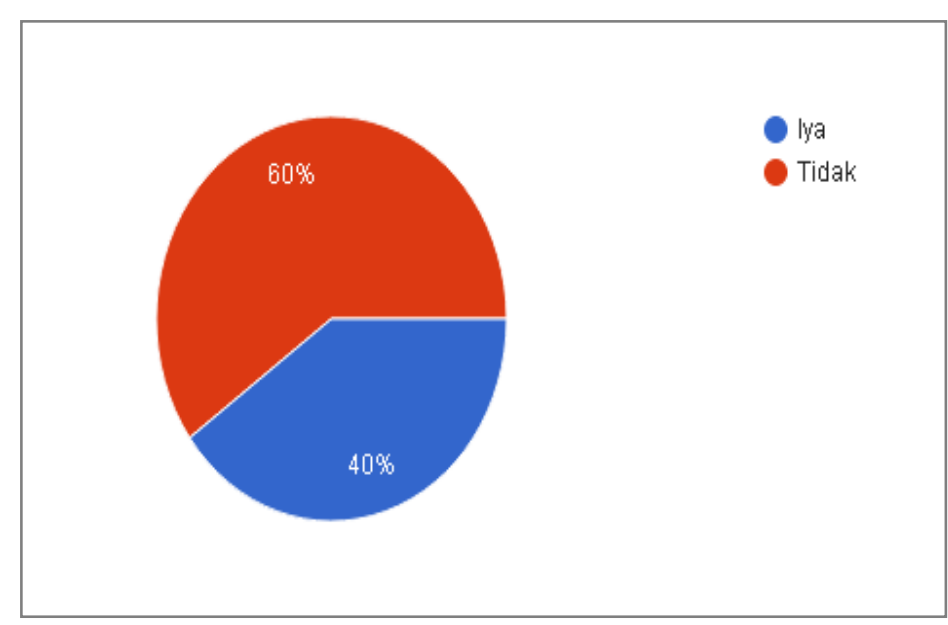

Gambar 5. Hasil pre test

Kesimpulan dari hasil pre test bahwasannya yang menyatakan iya artinya memahami perpustakaan berbasis teknologi informasi sebanyak 40\%, sedangkan $60 \%$ menyatakan "tidak" 
artinya mereka tidak tahu perpustakaan itu memiliki teknologi atau berbasis teknologi Informasi, ini sebagai bukti dari 13 peserta angk tidaktahuan terhadap perpustakaan berbasis teknologi Informasi sangat minim. Kegiatan yang dilakukan untuk mengurangi pemahaman bahwa peserta pelatihan tidak memahami kegiatan-kegiatan perpustakaan baik itu pengelolaan perpustakaan, teknologi informasi meliputi :

- Bimbingan pengelolaan perpustakaan "Pengembangan koleksi" berbasis teknologi informasi. Koordinasi dengan Kepala MTs Negeri 2 Malang, Mengidentifikasi persoalanpersoalan yang ada di perpustakaan Madrasah Tsanawiyah Negeri2 Malang, Memberikan bimbingan terkait draf usulan buku, Memberikan bimbingan terkait seleksi bahan pustaka, Melakukan pengembangan dengan memanfaatkan katalog online/daftar bibliografi online terbitan koleksi.

- Teknologi informasi. Menyiapkan berbagai keperluan untuk penginstalan aplikasi SLiMS, Meng-install-kan aplikasi SLiMS ke dalam komputer Perpustakaan MTs Negeri 2 Malang Dilakukan dalam $1 \mathrm{x}$ pertemuan.

- Layanan Perpustakaan berbasis teknologi Informasi. Memberikan bimbingan dalam penggunakan aplikasi/sofware SliMS yang telah disinstall masuk ke dalam menu sirkulasi.

- Pengolahan bahan pustaka berbasis teknologi informasi. Memberi pelatihan tentang menentukan tajuk subjek pada koleksi, klasifikasi bahan pustaka dengan menggunakan aplikasi SLiMS kepada petugas perpustakaan dan pustakawan Perpustakaan MTs Negeri 2 Malang Dilakukan dalam 1x pertemuan.

Dari uraian diatas dirumuskan dalam tabel dibawah ini.

Tabel 4. Kegiatan Pelatihan

\begin{tabular}{|c|c|c|}
\hline No & Kegiatan & Rancangan Kegiatan \\
\hline 1. & $\begin{array}{l}\text { Bimbingan pengelolaan } \\
\text { perpustakaan } \\
\text { "Pengembangan } \\
\text { koleksi" berbasis } \\
\text { teknologi informasi }\end{array}$ & $\begin{array}{ll}\text { - } & \text { Koordinasi dengan Kepala MTs Negeri } 2 \text { Malang } \\
\text { - } & \text { Mengidentifikasi persoalan-persoalan yang ada di } \\
\text { perpustakaan Madrasah Tsanawiyah Negeri } 2 \text { Malang } \\
\text { - } & \text { Memberikan bimbingan terkait draf usulan buku } \\
\text { - } & \text { Memberikan bimbingan terkait seleksi bahan pustaka } \\
\text { - } & \text { Melakukan pengembangan dengan memanfaatkan } \\
& \text { katalog online/daftar bibliografi online terbitan koleksi. }\end{array}$ \\
\hline 2 & Teknologi informasi & 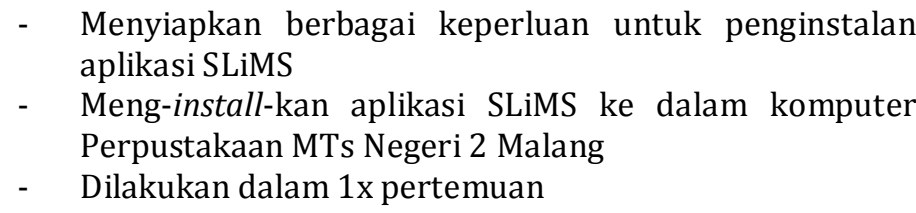 \\
\hline 3. & $\begin{array}{l}\text { Layanan Perpustakaan } \\
\text { berbasis teknologi } \\
\text { Informasi }\end{array}$ & $\begin{array}{l}\text { - Memberikan bimbingan dalam penggunakan } \\
\text { aplikasi/sofware SliMS yang telah disinstall masuk } \\
\text { ke dalam menu sirkulasi }\end{array}$ \\
\hline 4. & $\begin{array}{l}\text { Pengolahan bahan } \\
\text { pustaka } \\
\text { berbasis teknologi } \\
\text { informasi }\end{array}$ & $\begin{array}{l}\text { - Memberi pelatihan tentang menentukan tajuk subjek } \\
\text { pada koleksi, klasifikasi bahan pustaka dengan } \\
\text { menggunakan aplikasi SLiMS kepada petugas } \\
\text { perpustakaan dan pustakawan Perpustakaan MTs } \\
\text { Negeri 2 Malang } \\
\text { Dilakukan dalam 1x pertemuan }\end{array}$ \\
\hline
\end{tabular}



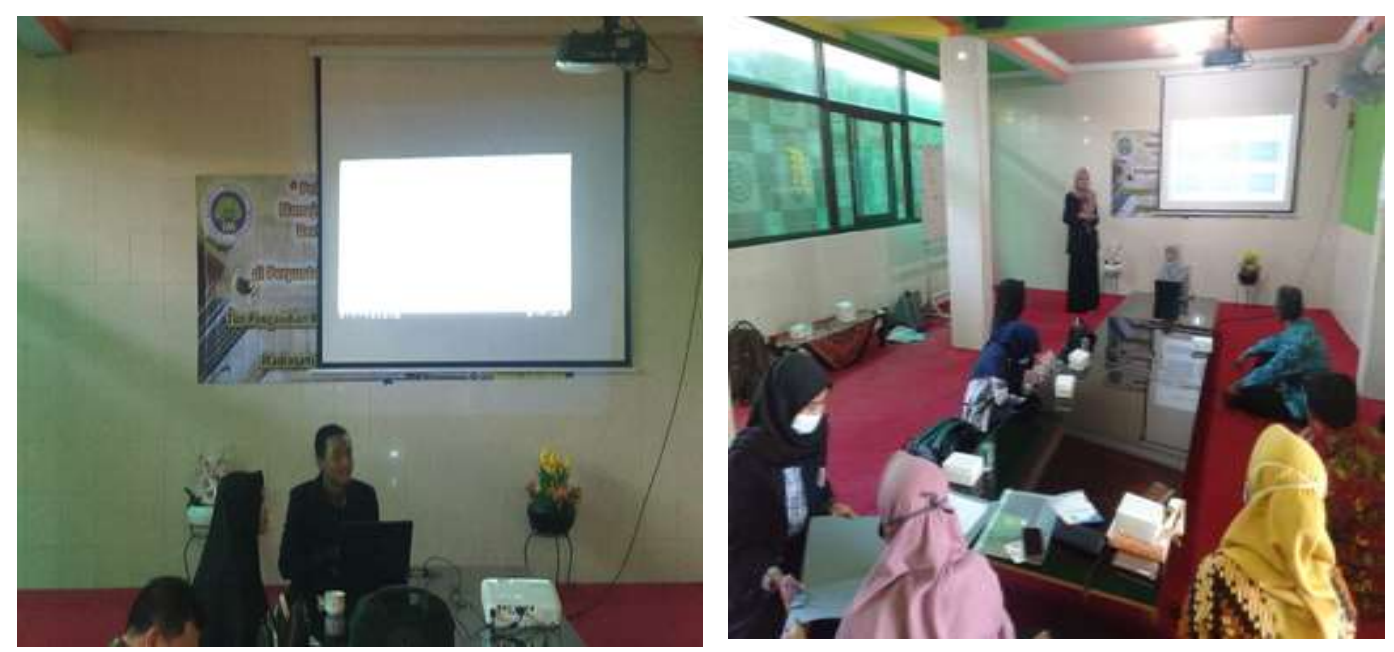

Gambar 6. Pemaparan materi

\section{B. Pembahasan}

\section{- Pos test}

Untuk mengetahui bahwa peserta memahami materi-materi yang disampaikan pemateri, maka pada kegiatan pengabdian ini dilakukan post test untuk bahan evaluasi berbentuk post test.

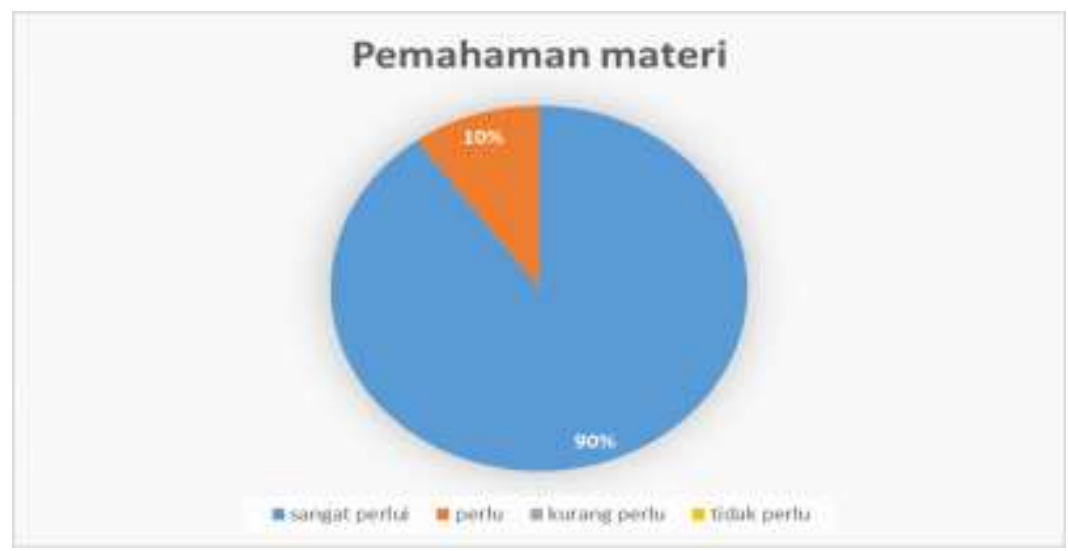

Gambar 7. Pemahaman materi

Hasil dari post tes bermanfaat sekali sebagai bahan evaluasi. Dilihat darigambar 7 sebesar $80 \%$ menyatakan sangat paham terhadap materi yang disampaikan, 15\%, menyatakan memahami materi yang disampaikan oleh pemateri, 5\% menyatakan cukup memahami materi yang diberikan oleh pemateri, ini sangat berbanding dengan hasil pre test yang menyatakan bahwa sebagian besar peserta tidak mengetahui sistem pengolahan dan teknologi informasi yang ada di perpustakaan sekolah 


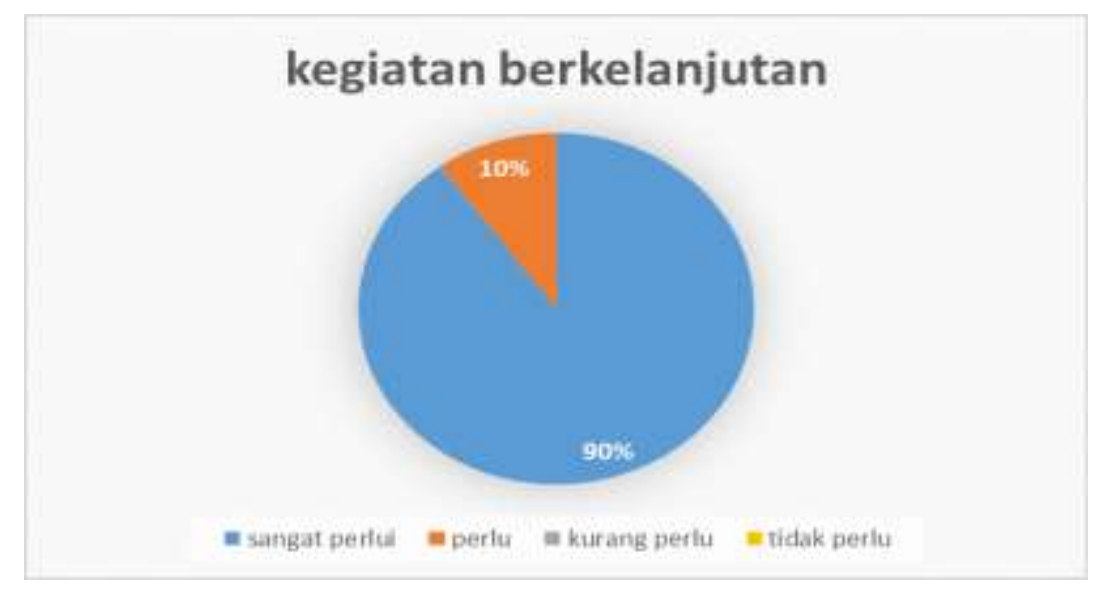

Gambar 8. Kegiatan berkelanjutan

Dari hasil post test didapati bahwa $90 \%$ peserta menginginkan kegiatan ini berkesinambungan artinya ada tindak lanjut untuk periode-periode berikutnya, $10 \%$ menyatakan perlu dilakukan dalam jangka waktu tertentu karena memiliki nilai manfaat untuk kemajuan dan perkembangan perpustakaan sekolah, khususnya MTsN2 Kota Malang.

\section{KESIMPULAN}

Hasil Kegiatan Pengabdian masyarakat yang telah dilaksanakan ini berjalan dengan lancar sesuai dengan tujuan yang diharapkan dari program ini, dan mendapatkan hasil yang baik. Ini terlihat dari antusias dari para peserta pelatihan ini dalam memahami berbagai macam materi dan juga ketika pemateri memberikan soal-soal pertanyaan banyak peserta bisa mengerjakan soal-soal tersebut. Serta hal yang terpenting yaitu peserta bisa mempraktekkan penerapan manajemen perpustakaan berbasis teknologi informasi. Walaupun masih ada beberapa kekurangan yaitu masih ditemukannya peserta ada yang masih kurang paham terhadap materi yang disampaikan oleh pemateri. Adapun keinginan dari kegiatan ini

- Memberikan kontribusi dalam peningkatan manajemen perpustakaan berbasis teknolog informasi berbasis teknologi informasi melalui pengabdian masyarakat

- Petugas perpustakaan, guru, dan pustakawan memahami tata kelola perpustakaan (pengembangan koleksi, layanan perpustakaan, sehingga bisa menjadikan perpustakaan sesuai dengan standar nasional yang diberlakukan

- Manajemen Perpustakaan berabasis Teknologi Informasi dengan ter-install-nyasoftware sistem otomasi perpustakaan SLiMS, beralihnya database manualmenjadi database otomasi dalam aplikasi SLiMS, serta petugas perpustakaandan pustakawan yang mampu mengoperasionalkan SLiMS

\section{DAFTAR PUSTAKA}

Jogiyanto. 2005. Sistem Teknologi Informasi (Pendekatan Terintegrasi : Konsep Dasar, Teknologi, Aplikasi, Pengembangan dan Pengelolaan). Yogyakarta : Andi.

Kadir, Abdul dan Terra Ch. Triwahyuni. 2003. Pengenalan Teknologi Informasi. Yogyakarta : Andi.

Marlinda, Linda. 2004. Sistem Basis Data. Yogyakarta : Andi.

Mulyanta, Edi S. 2005. Pengenalan Protokol Jaringan Wireless Komputer. Yogyakarta : Andi. 
Pendit, Putu Laxman dkk. 2007. Perpustakaan Digital : Perspektif Perpustakaan Perguruan Tinggi Indonesia. Jakarta : Sagung Seto.

Prasetyo, Eko. 2008. Pemrograman Web PHP \&MySQL : untuk Sistem Informasi Perpustakaan. Yogyakarta : Graha Ilmu.

Qalyubi, Syihabuddin dkk. 2007. Dasar-dasar Ilmu Perpustakaan dan Informasi. Yogyakarta : Jurusan Ilmu Perpustakaan dan Informasi - UIN Sunan Kalijaga Yogyakarta.

Supriyanto, Aji. 2007. Pengantar Teknologi Informasi. Jakarta : Salemba Infotek.

Supriyanto, Wahyu dan Ahmad Muhsin. 2007. Teknologi Informasi Perpustakaan : Strategi Perancangan Perpustakaan Digital. Yogyakarta : Kanisius.

Wicaksono, Hendro dkk. 2010. Manual Senayan Versi 4 : berdasarkan Senayan3-stable 14 (Selunga). Jakarta : Depdiknas.

Williams, Brian K. and Stacey C. Sawyer. 2003. Using Information Technology : a Practical Introduction to Computers \& Communications. Boston : McGraw-Hill. 